\title{
KONDYCJA FINANSOWA GOSPODARSTW ROLNYCH W REGIONACH FADN UNII EUROPEJSKIEJ I JEJ ZWIĄZEK Z PRODUKTYWNOŚCIĄ CZYNNIKÓW WYTWÓRCZYCH ${ }^{1}$
}

\author{
Bazyli Czyżewski, Lukasz Kryszak \\ *Katedra Edukacji i Rozwoju Kadr, Zespół Badawczy \\ Katedry Makroekonomii i Gospodarki Żywnościowej Uniwersytetu Ekonomicznego w Poznaniu \\ ${ }^{* *}$ Katedra Makroekonomii i Gospodarki Żywnościowej Uniwersytetu Ekonomicznego w Poznaniu \\ Kierownik Katedry: prof. dr hab. Andrzej Czyżewski
}

\begin{abstract}
Słowa kluczowe: sytuacja finansowa gospodarstw rolnych, TOPSIS, produktywność, regiony FADN

Key words: financial condition of farms, TOPSIS, productivity, FADN regions

S y n o p s i s. Cele badań to ocena kondycji finansowej reprezentatywnych gospodarstw rolnych w regionach FADN UE oraz identyfikacja zależności między kondycją finansową gospodarstw a produktywnością poszczególnych czynników wytwórczych, jak również produktywnością całkowitą (TFP). Wykorzystano syntetyczny miernik_oceny sytuacji finansowej gospodarstwa wyznaczony metodą TOPSIS oraz wskaźniki korelacji. Gospodarstwa reprezentatywne w regionach FADN UE charakteryzują się silnie zróżnicowaną sytuacją finansową, przy czym najwyższe wartości miernika syntetycznego odnotowano w regionach Europy Południowej (Grecja, Portugalia, część Hiszpanii i Włoch). Gospodarstwa w tych regionach odznaczały się relatywnie niskim poziomem zadłużenia, korzystną sytuacją w zakresie obsługi długu, a także wysoką rentownością i sprawnością działania. Zaobserwowano istotne statystycznie związki między kondycją finansową gospodarstw a produktywnością czynników wytwórczych - dodatnie w przypadku czynnika kapitału i produktywności całkowitej TFP, a ujemne w odniesieniu do pracy i ziemi.
\end{abstract}

\section{WPROWADZENIE}

Kondycja finansowa gospodarstwa rolnego należy do kluczowych elementów jego funkcjonowania. $Z$ tego wynika dynamiczny rozwój różnych kierunków metodycznych w badaniach nad sytuacją finansową gospodarstw [Soliwoda 2014]. Podstawowym sposobem oceny tej sytuacji pozostaje tradycyjna analiza wskaźnikowa oraz modele wykorzystujące mierniki cząstkowe obliczone w wyniku jej stosowania [por. Góral i in. 2015]. W badaniach z zakresu ekonomii rolnej często wykorzystuje się formułę Du Ponta, zarówno w wersji podstawowej, jak i w licznych zmodyfikowanych ujęciach [Moss i in. 2009, Gołaś 2009]. Wśród innych kierunków badań nad finansami można wymienić stosowanie

\footnotetext{
Artykuł sfinansowano ze środków Narodowego Centrum Nauki w ramach projektu badawczego nr 2016/23/N/HS4/03453 pt. „Determinanty dochodów rolniczych w_regionach UE z uwzględnieniem relacji zasobowych i produktywności czynników wytwórczych".
} 
modeli ekonometrycznych, w których ocenia się wpływ różnorodnych czynników na jeden z elementów kondycji finansowej, np. rentowność [Gołaś, Kurzawa 2014, Franc-Dąbrowska 2009]. Analiza wskaźnikowa pozwala na wielowątkową i dość dokładną ocenę sytuacji finansowej. Z drugiej strony, zastosowanie miernika syntetycznego ułatwia porównywanie jednostek, szczególnie w warunkach dużej ich liczebności oraz pozwala na wyznaczenie grup jednostek o podobnych uwarunkowaniach [por. Majchrzak, Wysocki 2007].

Obecnie zaleca się, aby na sytuację finansową gospodarstwa patrzeć przez pryzmat innych jego charakterystyk. Potrzeba zatem ujęcia holistycznego [Soliwoda 2014]. Ponadto, wymiar finansowy gospodarstwa winien stać się dodatkowym elementem analizy w kontekście zrównoważenia gospodarstwa rolnego, obok aspektu ściśle ekonomicznego, społecznego i środowiskowego [Soliwoda 2015]. W odniesieniu do finansów gospodarstwa pojawiają się koncepcje, takie jak zrównoważona stopa wzrostu finansowego [Escalarte i in. 2009].

Przyjęcie szerszej perspektywy badawczej w odniesieniu do finansów gospodarstwa rolnego prowadzi do pytania o związki sytuacji finansowej i produktywności czynników wytwórczych. Intensyfikacja produkcji oraz unowocześnienie metod gospodarowania wiążą się zwykle z koniecznością zadłużenia gospodarstwa oraz spadkiem jednostkowej rentowności. Jednocześnie w rolnictwie następują zmiany strukturalne [Goddard i in. 1993] związane ze zmianami relatywnych cen czynników produkcji. Cena czynnika kapitału na tle pracy staje się niższa, co powoduje relatywny wzrost zastosowania tego pierwszego faktora. Tym samym produktywność kapitału obniża się, natomiast produktywność pracy (podobnie ziemi) wzrasta. Choć zależności te mają charakter ogólny, a na tle globalnym rolnictwo w Europie jest na wysokim poziomie rozwoju, to różnice w produktywności w poszczególnych krajach i regionach pozostają znaczne [Restuccia i in. 2008]. Dodatkowe znaczenie ma realizowany na danym terenie model rolnictwa związany ze specyfiką regionalną (np. regiony śródziemnomorskie) [Jepsen i in. 2015]. Związki między sytuacją finansową a produktywnością w gospodarstwach rolnych nie są zatem oczywiste.

Powyższe rozważania skłaniają do przyjęcia w niniejszej pracy dwóch celów szczegółowych. Po pierwsze, ocena kondycji finansowej reprezentatywnych gospodarstw rolnych w regionach FADN UE; po drugie, identyfikacja zależności między kondycją finansową gospodarstw a produktywnością poszczególnych czynników wytwórczych, jak również produktywnością całkowitą (TFP).

\section{METODYKA BADAŃ}

W pierwszym etapie oceniano kondycję finansową reprezentatywnych ${ }^{2}$ gospodarstw rolnych w regionach FADN UE (z wyłączeniem terytoriów zamorskich Francji) z wykorzystaniem miernika syntetycznego wyznaczanego za pomocą metody TOPSIS (ang. Technique for Order Preference by Similarity to an Ideal Solution) [Wysocki 2010]. Na podstawie analizy literatury wybrano 23 wskaźniki cząstkowe, które reprezentują wszystkie aspekty sytuacji finansowej gospodarstwa (płynność, zadłużenie i jego obsługa, rentowność, sprawność działania) i są możliwe do policzenia na podstawie publicznie dostępnych da-

\footnotetext{
W polu obserwacji FADN znajdują się jedynie gospodarstwa o określonej wielkości ekonomicznej, które w danym kraju wytwarzają przynajmniej 90\% wartości produkcji. W Polsce systemem FADN objęto około połowę gospodarstw, a próg wejścia ustalono na poziomie 4 tys. euro standardowej produkcji. Badane gospodarstwa są zatem reprezentatywne wyłącznie dla gospodarstw współpracujących z FADN.
} 
nych FADN, a jednocześnie nie zawierają informacji na temat produktywności czynników wytwórczych. Po obliczeniu wartości tych wskaźników zrezygnowano z uwzględniania w dalszych analizach miar płynności: bieżącej, szybkiej i gotówkowej oraz wskaźnika cyklu zobowiązań. W mianowniku wszystkich tych wskaźników znajdują się bowiem zobowiązania krótkoterminowe. Zobowiązania o krótkim okresie zapadalności odgrywają zwykle relatywnie małą rolę w przypadku gospodarstw rolnych, a w przypadku części regionów w ogóle nie występowały, co uniemożliwiało ich obliczenie. Ze względu na występowanie ujemnych inwestycji oraz brak zapasów w niektórych przypadkach zrezygnowano także z uwzględniania rentowności inwestycji (ROI) oraz wskaźnika rotacji zapasów. Pozostałe 17 wskaźników podlegało dalszym analizom. Procedura ustalenia wartości wskaźnika syntetycznego przebiegała w kilku etapach:

1. Spośród zbioru merytorycznie akceptowalnych wskaźników cząstkowych do budowy miary syntetycznej wybierano te, które charakteryzowały się wystarczającym poziomem współczynnika zmienności i jednocześnie nie były nadmiernie skorelowane z innymi wskaźnikami. Oceny korelacji dokonano poprzez budowę macierzy korelacji między zmiennymi a następnie macierzy odwrotnej. Dalej analizowano elementy diagonalne macierzy odwrotnej. Wartości znacznie przekraczające liczbę 10 wskazują na niewłaściwe uwarunkowanie numeryczne macierzy i tym samym nadmierne skorelowanie danej cechy z pozostałymi cechami. Z macierzy korelacji obejmującej 17 wskaźników eliminowano kolejno zmienne odznaczające się najwyższym poziomem skorelowania z innymi zmiennymi. Procedura doprowadziła do wyodrębnienia 8 zmiennych, które ostatecznie posłużyły do budowy miary syntetycznej.

2. W kolejnym kroku przeprowadzono unitaryzację zerowaną cech prostych przy jednoczesnym przekształceniu destymulant w stymulanty. Pozwala to ujednolić charakter cech oraz sprowadzić poszczególne cechy do porównywalnej postaci (cechy przyjmują wartości od 0 do 1). Unitaryzację przeprowadzono na podstawie następujących formuł:

- stymulanty: $z_{i j}=\frac{x_{i k}-\min _{i}\left\{x_{i k}\right\}}{\max _{i}\left\{x_{i k}\right\}-\min _{i}\left\{x_{i k}\right\}},(i=1,2, \ldots, n ; j=1,2, \ldots, k)$

- destymulanty: $z_{i j}=\frac{\max _{i}\left\{x_{i k}\right\}-x_{i k}}{\max _{i}\left\{x_{i k}\right\}-\min _{i}\left\{x_{i k}\right\}},(i=1,2, \ldots, n ; j=1,2, \ldots, k)$

gdzie: $\min _{i}\left\{x_{i k}\right\}$ - minimalna wartość $k$-tej cechy, $\max _{i}\left\{x_{i k}\right\}$ - maksymalna wartość $k$-tej cechy, $i$ - oznacza obiekt (w tym przypadku gospodarstwo reprezentatywne w regionie).

3. W trzecim kroku ustalono wagi poszczególnych wskaźników za pomocą metody CRITIC (ang. Criteria Importance Through Intercriteria Correlation) [Diakoulaki i in. 1995, Deng i in. 2000]. Przyjęto zatem założenie, podobnie jak w pracy [Bieniasz i in. 2013], że wpływ poszczególnych cech prostych na wartość miary syntetycznej nie jest jednakowy. Współczynniki wagowe w metodzie CRITIC ustala się przy wykorzystaniu odchyleń standardowych oraz korelacji między wskaźnikami. Charakterystyczną cechą tej metody jest przypisanie relatywnie większych wag cechom, które odznaczają się wysokim poziomem zmienności i jednocześnie niskim skorelowaniem z innymi cechami. Współczynniki wagowe wyznaczono za pomocą następujących formuł:

$$
w_{j}=\frac{c_{j}}{\sum_{k=1}^{K} c_{k}}, j=1,2, \ldots . K ; c_{j}=s_{j(z)} \sum_{k=1}^{K}\left(1-r_{j k}\right), j=1,2, \ldots . K
$$


gdzie: $c_{j}$ - miernik pojemności informacyjnej $j$-tej cechy, $s_{j(z)}$ oznacza odchylenie standardowe obliczone $z$ wartości znormalizowanych $j$-tej cechy, $r_{j k}$ - współczynnik korelacji między cechą $j$-tą i $k$-tą. Suma współczynników wynosi 1 . W kolejnym kroku wyznaczone znormalizowane wartości cech prostych przemnaża się przez odpowiednie współczynniki wagowe $w_{j}\left(z_{i j}^{*}=z_{i j} * w_{j}\right)$.

4. W kroku czwartym obliczone zostały odległości euklidesowe poszczególnych jednostek od wzorca i antywzorca rozwoju. Uwzględnianie odległości zarówno od wzorca, jak i antywzorca wyróżnia metodę TOPSIS na tle innych metod, np. wskaźnika Hellwiga. Odległości euklidesowe obliczono na podstawie następujących formuł’

$d_{i}^{+}=\sqrt{\sum_{j=1}^{K}\left(z_{j}^{*}-z_{j}^{+}\right)^{2}}$ od wzorca rozwoju

$d_{i}^{+}=\sqrt{\sum_{j=1}^{K}\left(z_{j}^{*}-z_{j}^{-}\right)^{2}}$ od antywzorca rozwoju

gdzie:

$z_{j}^{+}=\left(\max \left(z_{i 1}^{*}\right), \max \left(z_{i 2}^{*}\right), \ldots, \max \left(z_{i K}^{*}\right)\right)=\left(z_{1}^{+}, z_{2}^{+}, \ldots, z_{K}^{+}\right)$

$z_{j}^{-}=\left(\max \left(z_{i 1}^{*}\right), \max \left(z_{i 2}^{*}\right), \ldots, \max \left(z_{i K}^{*}\right)\right)=\left(z_{1}^{+}, z_{2}^{+}, \ldots, z_{K}^{+}\right)$

5. Kolejnym etapem było wyznaczenie wartości cechy syntetycznej $q_{i}$ za pomocą formuły: $q_{i}=\frac{d_{i}^{-}}{d_{i}^{+}+d_{i}^{-}},(i=1,2, \ldots, n)$

6. Ostatnim etapem badań było grupowanie regionów pod względem sytuacji finansowej. W tym celu uporządkowano regiony według wartości miary syntetycznej, a następnie wyznaczono 4 klasy regionów przy użyciu średniej arytmetycznej i odchylenia standardowego:

- $\quad$ klasa $\mathrm{I}=q_{i} \geq \bar{q}+s_{q}$,

- $\quad$ klasa II $=\bar{q}+s_{q}>q_{i} \geq \bar{q}$,

- $\quad$ klasa III $=\bar{q}>q_{i} \geq \bar{q}-s_{q}$,

- $\quad$ klasa IV $=q_{i}<\bar{q}-s_{q}$,

gdzie $\bar{q}$ oznacza średnią wartość miary syntetycznej, natomiast $s_{q}$ odchylenie standardowe.

Taką sekwencyjną analizę przeprowadzono na średnich danych za lata 2005-2007 oraz 2013-2015, co pozwoliło na uchwycenie dynamicznych aspektów badanych zjawisk, jak również kontrolę zjawiska odchyleń związanych ze zmianami koniunkturalnymi. Ze względu na brak możliwości obliczenia niektórych formuł w analizach TOPSIS pominięto regiony Madryt i Kalabria, a w podokresie 2013-2015 również Ligurię.

Hepu Deng, Chung-Hsing Yeh i Robert Willis [2000] sugerowali, że do powyższych obliczeń można podejść w odmienny sposób. Nalezy obliczać odległości od wzorca i antywzorca rozwoju na danych standaryzowanych (bez uwzględniania wag), a dopiero otrzymane odległości przemnażać przez obliczone współczynniki wagowe. Obliczono zatem wartości miary syntetycznej (dla lat 2005-2007) również przy użyciu metody zaproponowanej przez H. Denga, Ch. Yeha i R. Willisa [2000]. Otrzymane wyniki były zazwyczaj nieco niższe (średnio o 0,11), jednak ranking regionów na podstawie badanej cechy był bardzo podobny wartość współczynnika korelacji rang Spearmana pomiędzy dwoma rankingami wyniosła 0,97. 
W drugiej części opracowania obliczone wartości syntetycznego miernika kondycji finansowej gospodarstw skorelowano z miarami produktywności. Były to miary produktywności cząstkowej (pracy, ziemi i kapitału) ${ }^{4}$ oraz miara TFP zaproponowana przez Tomasza Tokarskiego [Dańska-Borsiak 2011] obliczana według formuły:

$$
T F P_{i t}=\frac{\left(\frac{Y_{i t}}{L_{i t}}\right)}{\left(\frac{K_{i t}}{L_{i t}}\right)^{\alpha}}
$$

lub w wersji zmodyfikowanej na potrzeby gospodarstwa rolnego:

$$
T F P_{i t}=\frac{\left(\frac{Y_{i t}}{L_{i t}}\right)}{\left(\frac{K_{i t}}{L_{i t}}\right)^{\alpha}+\left(\frac{Z_{i t}}{L_{i t}}\right)^{\beta}}
$$

W świetle powyższych formuł TFP jest relacją wydajności pracy $\left(\frac{Y_{i t}}{L_{i t}}\right)$ do technicznego uzbrojenia pracy $\left(\frac{K_{i t}}{L_{i t}}\right)$ lub technicznego uzbrojenia pracy i uzbrojenia czynnika pracy w ziemię $\left(\frac{Z_{i t}}{L_{i t}}\right)$. Obliczanie wartości TFP wymaga wcześniejszego obliczenia wartości współczynników $\alpha$ i $\beta$. Ustalenie wartości współczynników następuje przez estymację (np. za pomocą modelu regresji panelowej z efektami stałymi) modelu postaci:

$$
\ln \left(\frac{Y_{i t}}{L_{i t}}\right)=\sum_{i=1} d_{i}+g t+\alpha \ln \left(\frac{K_{i t}}{L_{i t}}\right)
$$

lub

$$
\ln \left(\frac{Y_{i t}}{L_{i t}}\right)=\sum_{i=1} d_{i}+g t+\alpha \ln \left(\frac{K_{i t}}{L_{i t}}\right)+\beta \ln \left(\frac{Z_{i t}}{L_{i t}}\right)
$$

gdzie: $t$ - kolejny okres (symbolizujący postęp techniczny w sensie Hicksa), $d_{i}$ - efekt indywidualny regionu.

Wartości współczynników w równaniach (3) i (4) zostały wyznaczone na danych panelowych obejmujących wszystkie badane regiony w okresie 2004-2015.

Analiza wykresów rozrzutu wskazała, że w niektórych przypadkach związek między kondycją finansową i produktywnością czynników produkcji w gospodarstwie rolnym może mieć charakter inny niż liniowy, dlatego obliczono zarówno wskaźnik korelacji Pearsona, jak również wskaźniki nieparametryczne (współczynnik korelacji rang Spearmana i współczynnik tau Kendalla).

$4 \quad$ Miarą efektu we wskaźnikach produktywności była całkowita realna wartość produkcji. Przez kapitał rozumiano koszty (zużycia pośredniego, amortyzacji, czynszów i odsetek), pracę wyrażono w jednostkach AWU, natomiast ziemię w ha. W celu zapewnienia porównywalności w czasie i przestrzeni surowe dane FADN dotyczące produkcji i kapitału zostały przeliczone według stałego kursu walut krajowych do euro z 2004 roku (lub roku wejścia do strefy euro, jeśli nastąpiło w badanym okresie), a następnie zdeflowane z wykorzystaniem indeksów cen zaczerpniętych z Rachunków Ekonomicznych dla Rolnictwa Eurostat. 


\section{WYNIKI BADAŃ}

Na podstawie procedury opisanej w części metodycznej do analiz oraz konstrukcji miernika syntetycznego wykorzystano 8 wskaźników cząstkowych opisujących różne aspekty kondycji finansowej gospodarstwa (tab. 1.). Do analizy włączono wskaźnik kapitału obrotowego w dniach obrotu, który w przypadku gospodarstwa rolnego określa liczbę dni obrotu, na jaką wystarcza kapitał obrotowy (aktywa obrotowe - zobowiązania krótkoterminowe). Gdy rośnie sprzedaż, istotne jest, aby proporcjonalnie zwiększać również kapitał obrotowy, co pomaga utrzymać płynność.

Tabela 1. Wskaźniki cząstkowe wykorzystane do budowy syntetycznego miernika kondycji finansowej

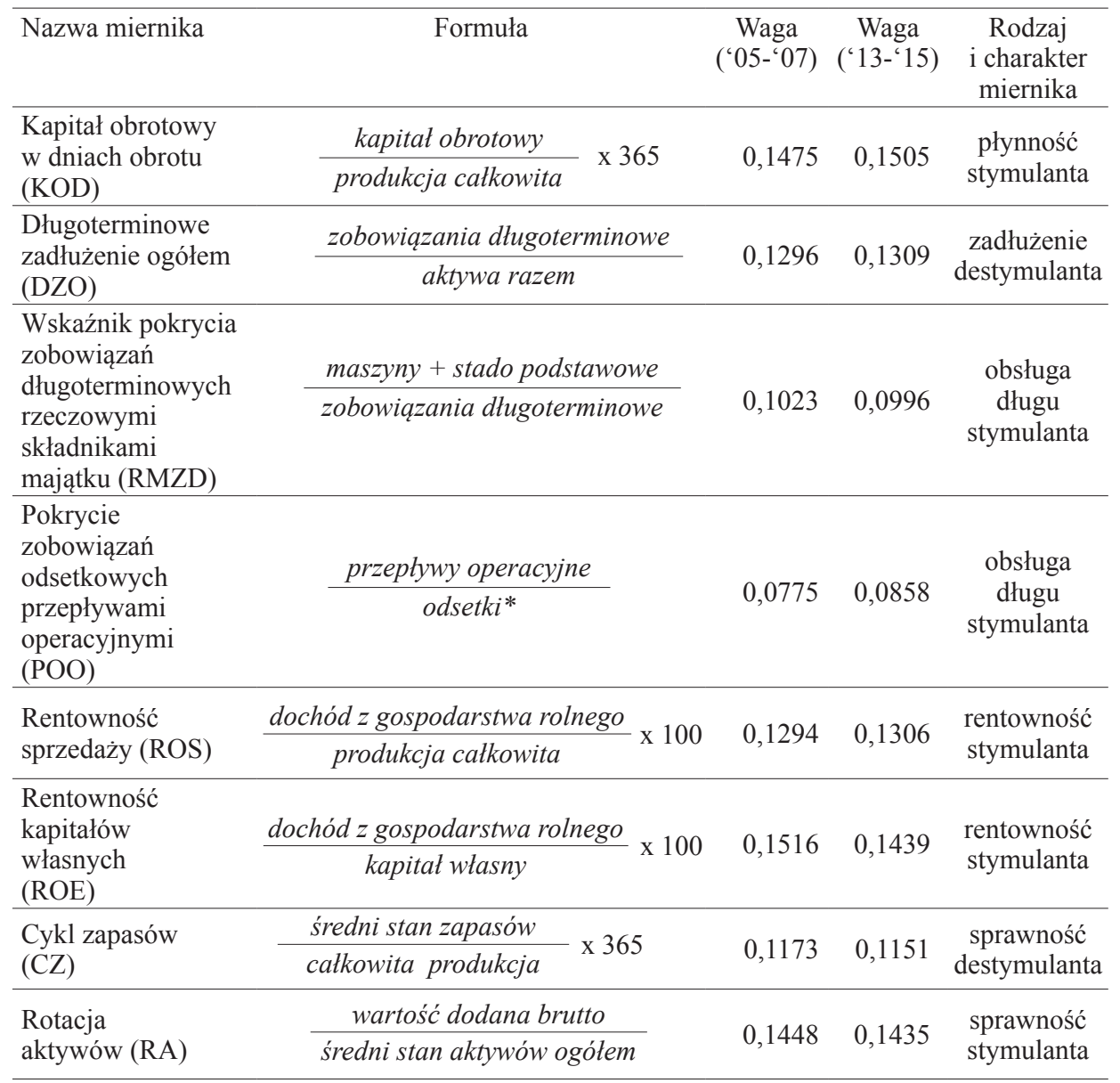

* przez odsetki rozumiano bilans odsetek płaconych i otrzymywanych, ponieważ od 2014 roku osobne dane na temat odsetek płaconych i otrzymywanych nie są gromadzone. Odsetki otrzymane mają jednak w rolnictwie znaczenie marginalne.

Źródło: obliczenia własne na podstawie danych FADN. 
W przypadku gospodarstwa rolnego ważną rolę odgrywa długoterminowe zadłużenie gospodarstwa. Dążenie do poprawy konkurencyjności gospodarstwa wiąże się bowiem ze znacznymi nakładami inwestycyjnymi na zakup sprzętu lub ziemi. Mimo istniejącego systemu wsparcia inwestycji w rolnictwie, istotną część kosztów inwestycji ponoszą sami rolnicy, co powoduje konieczność zaciągania wieloletnich kredytów. Wysoki poziom zadłużenia gospodarstwa może utrudnić jego bieżące funkcjonowanie. W sytuacji spadku dochodów (np. na skutek niższych plonów, które nie zostały skompensowane odpowiednim wzrostem cen) istnieje ryzyko konieczności ograniczenia nie tylko prywatnej konsumpcji rodziny rolniczej, ale również wydatków na cele produkcyjne, co może skutkować dalszym spadkiem przychodów (niekiedy również dochodu) i tym samym obniżeniem poziomu życia rodziny rolniczej. Kolejne 2 wskaźniki dotyczą zdolności do obsługi długu. Wskaźnik pokrycia zobowiązań długoterminowych rzeczowymi składnikami majątku ${ }^{5}$ wskazuje na relację zadłużenia długoterminowego i majątku trwałego. Pokazuje on, czy w sytuacji kryzysowej upłynnienie majątku trwałego wystarcza na spłatę zobowiązań. Kolejny wskaźnik (pokrycie zobowiązań odsetkowych przepływami operacyjnymi) obrazuje sytuację gospodarstwa w zakresie jego zdolności do opłacania odsetek z wyniku działalności operacyjnej. Wskaźnik ten może być też zatem traktowany do pewnego stopnia jako miara płynności. Kolejne 2 wskaźniki dotyczą rentowności gospodarstwa rolnego, zarówno zainwestowanego kapitału, jak i rentowności produkcji. Należy jednak zaznaczyć, że niska rentowność obserwowana niekiedy w gospodarstwach Europy Zachodniej nie jest fundamentalnym problemem, jeśli produkcja prowadzona jest w odpowiednio dużej skali. Ostatnie 2 wskaźniki dotyczą sprawności działania. Sprawnie działające gospodarstwo powinno relatywnie szybko upłynniać zapasy. Pożądaną jest sytuacja, gdy cykl zapasów ulega skróceniu. Wskaźniki rotacji informują o wartości sprzedaży (w tym przypadku netto), która zostanie wygenerowana z jednego euro posiadanych aktywów. Niskie wartości wskaźnika mogą też wskazywać na przerost majątku (aktywów) względem zdolności do generowania sprzedaży. Choć wagi poszczególnych wskaźników różniły się w obu badanych podokresach, to można powiedzieć, że najważniejsze znaczenie dla konstrukcji miernika syntetycznego miały wskaźnik kapitału obrotowego w dniach obrotu, rentowność kapitałów własnych oraz rotacja aktywów.

Gospodarstwa reprezentatywne w regionach FADN UE charakteryzowały się bardzo zróżnicowaną sytuacją finansową, na co wskazują wysokie wartości współczynnika zmienności dla poszczególnych wskaźników cząstkowych (por. tab. 2.). Wynika to z wielu czynników, takich jak dominujące kierunki produkcji, uwarunkowania zasobowe i majątkowe, a także z modelu rozwoju rolnictwa (np. rolnictwo wybitnie intensywne versus ekstensywne). Jeśli chodzi o kapitał obrotowy w dniach obrotu, to najwyższe jego wartości (czasem przekraczające nawet $1000 \mathrm{dni}$ ) w obu podokresach notowano w regionach (z pewnymi wyjątkami) hiszpańskich (pierwszy podokres) i włoskich (drugi podokres). Wynikało to z relatywnie dużych wartości aktywów obrotowych (w regionach hiszpańskich stanowiły one średnio $31 \%$ ogółu aktywów wobec $24 \%$ w całej populacji) przy niewysokich wartościach zobowiązań krótkoterminowych, co skutkowało wysokimi wartościami kapitału obrotowego. Niskie wartości tego wskaźnika notowano z kolei w części regionów niemieckich, a także greckich. Joanna Bereżnicka zwróciła jednak uwagę, że wysoki poziom kapitału obrotowego może skutkować nadpłynnością i tym samym nieefektywnym alokowaniem środków pozostających w dyspozycji gospodarstwa

Z licznika wskaźnika celowo wyeliminowano ziemię, gdyż uznano, że jest to fundamentalny element potencjału produkcyjnego gospodarstwa, a jego sprzedaż jest relatywnie bardziej skomplikowana. 
Tabela 2. Statystyki opisowe dla cząstkowych wskaźników kondycji finansowej gospodarstw rolnych w regionach FADN UE

\begin{tabular}{lrrrrrr}
\hline Wskaźnik* & MIN & \multicolumn{1}{c}{ MAX } & Mediana & $\begin{array}{c}\text { Dolny } \\
\text { kwartyl }\end{array}$ & $\begin{array}{c}\text { Górny } \\
\text { kwartyl }\end{array}$ & $\begin{array}{c}\text { Współczynnik } \\
\text { zmienności [\%] }\end{array}$ \\
\hline \multicolumn{7}{c}{$2005-2007$} \\
KOD & 17,249 & 1256,159 & 208,325 & 145,657 & 332,478 & 81,3 \\
DZO & 0,000 & 0,511 & 0,076 & 0,018 & 0,214 & 95,0 \\
RMZD & 0,189 & 190,640 & 2,011 & 1,155 & 7,039 & 236,2 \\
POO & 1,095 & 7598,611 & 19,282 & 13,148 & 112,349 & 392,0 \\
ROS [\%] & $-9,5$ & 71,6 & 31,3 & 22,2 & 46,0 & 49,7 \\
ROE [\%] & $-3,3$ & 22,1 & 9,4 & 6,0 & 14,0 & 52,7 \\
CZ & 0,000 & 357,152 & 29,557 & 14,672 & 57,717 & 117,0 \\
RA & 0,039 & 0,340 & 0,154 & 0,109 & 0,228 & 40,3 \\
\hline \multicolumn{7}{c}{$2013-2015$} \\
KOD & 36,058 & 1307,445 & 215,739 & 128,837 & 464,457 & 85,4 \\
DZO & 0,000 & 0,555 & 0,076 & 0,018 & 0,218 & 96,3 \\
RMZD & 0,162 & 847,456 & 1,802 & 1,015 & 6,474 & 356,4 \\
POO & 1,925 & 13856,667 & 26,071 & 13,393 & 154,462 & 358,1 \\
ROS [\%] & 2,5 & 68,5 & 25,6 & 16,2 & 40,6 & 52,8 \\
ROE [\%] & 1,2 & 23,5 & 7,6 & 5,5 & 11,6 & 51,8 \\
CZ & 0,000 & 334,289 & 29,071 & 9,427 & 62,686 & 115,5 \\
RA & 0,038 & 0,336 & 0,134 & 0,100 & 0,210 & 43,0 \\
\hline
\end{tabular}

* nazwy wskaźników cząstkowych jak w tabeli 1.

Źródło: obliczenia własne na podstawie danych FADN.

[Bereżnicka 2011]. Porównując wartości mediany dla obu badanych podokresów, można zauważyć nieznaczny przeciętny wzrost wartości wskaźnika, co wskazuje na ogólną poprawę płynności gospodarstw rolnych. Jeśli chodzi o zadłużenie długoterminowe, to (w obu podokresach) gospodarstwa rolne w niektórych regionach południowych (głównie włoskich i greckich) nie wykazywały prawie żadnego zadłużenia, natomiast na drugim biegunie znalazły się niektóre regiony północnej Francji, Holandia czy Dania. Na tych obszarach gospodarstwa realizowały wysoce specjalistyczny model produkcji, który wymaga znacznych inwestycji, co skutkuje wysokim poziomem zadłużenia długoterminowego. Jego wartość przekraczała w tych regionach 30\% wartości aktywów ogółem. Poziom zadłużenia długoterminowego gospodarstw rolnych w regionach FADN UE nie uległ istotnym zmianom w obu podokresach. Poziom pokrycia zobowiązań długoterminowych majątkiem trwałym najwyższy był również w regionach południowych, co wynikało przede wszystkim z niskiego poziomu zobowiązań. $Z$ kolei w niektórych regionach francuskich, niemieckich, w Belgii, Holandii czy Danii, wartość maszyn i stada podstawowego była niższa niż wartość zobowiązań. Ogólnie w badanej grupie regionów przeciętna wartość wskaźnika w latach 2013-2015 uległa obniżeniu w porównaniu do podokresu 2005-2007.

Poprawiła się wartość wskaźnika pokrycia zobowiązań odsetkowych przepływami operacyjnymi. Po raz kolejny najwyższymi wartościami wskaźnika charakteryzowały się gospodarstwa w regionach południowych (niskie zadłużenie przekładało się na niskie wartości odsetek), natomiast najniższe wartości zaobserwowano w regionach Europy Północnej i Zachodniej. Porównując podokresy 2005-2007 oraz 2013-2015, można zauważyć pogorszenie przeciętnych 
wartości rentowności, zarówno sprzedaży (ROS), jak i kapitału (ROE), przy jednoczesnym zmniejszeniu różnic między regionem o najwyższej i najniższej produktywności. Warto też zwrócić uwagę, że w drugim podokresie w żadnym z regionów nie odnotowano ujemnej rentowności. Bardzo wysoką rentowność sprzedaży przekraczającą 50\% (w obu podokresach) notowano w regionach włoskich, greckich czy hiszpańskich, co wynikało z podejmowanych kierunków produkcji, które wiążą się z wysokimi marżami. Niska rentowność sprzedaży charakterystyczna była zaś dla regionów Europy Środkowej, gdzie dominowały duże gospodarstwa (wschodnie Niemcy, Czechy, Słowacja, Węgry), a także dla Danii.

Odmienną sytuację zanotowano w zakresie rentowności kapitału własnego. Najwyższe wartości osiągano bowiem w regionach francuskich, portugalskich (drugi podokres) oraz na Litwie i Łotwie. Niską wartość ROE osiągano z kolei na Słowacji, w Słowenii oraz Europie Północnej (Wielka, Brytania, Szwecja, Irlandia). Największą sprawnością w zakresie rotowania zapasami (najkrótszy cykl zapasów) osiągano w niektórych regionach hiszpańskich, włoskich oraz w zachodnich Niemczech, co wynikało z utrzymywania relatywnie niewielkiej ilości zapasów w relacji do sprzedaży. Z kolei najdłuższy cykl zapasów notowano w części regionów francuskich, szczególnie w zachodniej części kraju. Przeciętny cykl zapasów w obu podokresach był bardzo podobny.

W latach 2013-2015 pogorszyła się przeciętna wartość rotacji aktywów, a więc zdolność gospodarstw do generowania przychodów ze sprzedaży z jednostki aktywów. Najefektywniej aktywa wykorzystywane były w regionach francuskich, niemieckich (głównie regiony wschodnie w pierwszym podokresie), a także np. na Słowacji. W regionach tych z jednego euro zaangażowanych aktywów udawało się generować ponad 20 centów sprzedaży. $Z$ kolei w niektórych regionach północnych (regiony brytyjskie, Dania), a także w części regionów włoskich i w Holandii wartość rotacji aktywów była niższa, częstokroć z jednego euro aktywów generowano poniżej 10 centów przychodu ze sprzedaży, co może wskazywać na nadmiar aktywów w relacji do prowadzonych kierunków produkcji.

Na podstawie kryterium średniej i odchylenia standardowego wyznaczono 4 grupy regionów o odpowiednio: wysokich, średnio wysokich, średnio niskich i niskich wartościach wskaźnika syntetycznego (por. tabela 3 oraz rys. 1. i 2.). W grupie regionów o najwyższych wartościach wskaźnika syntetycznego znalazły się 22 regiony w podokresie 2005-2007 i 23 regiony w okresie 2013-2015. Były to przede wszystkim regiony greckie, portugalskie i niektóre regiony hiszpańskie i włoskie. Grupa ta osiągała średnio najbardziej korzystne wyniki w niemal wszystkich (poza rotacją aktywów w pierwszym podokresie) badanych kategoriach szczegółowych. Szczególnie należy wyróżnić niski poziom zadłużenia (i co za tym idzie - sprawną jego obsługę), relatywnie krótki cykl zapasów i wysoki poziom rentowności sprzedaży. Poziom rentowności kapitałów własnych również był najwyższy, ale w tym przypadku różnice między grupami regionów nie były tak istotne.

Badania prowadzone wyłącznie na próbie polskich gospodarstw FADN [Wasilewski, Mądra 2008] wskazywały na nieco inne zależności. Mianowicie wraz ze wzrostem poziomu zadłużenia wzrastał poziom ROE. Świadczy to o ważnej roli specyfiki regionalnej w badaniu kondycji finansowej gospodarstw ${ }^{6}$. Z drugiej strony Mirosław Wasilewski i Tomasz Felczak wskazali na występowanie pozytywnego związku między korzystnymi wynikami finansowymi a „konserwatyzmem zarządczym”, który przejawia się m.in. w niechęci do nadmiernego zadłużania [Wasilewski, Felczak 2011]. W grupie regionów

W przywołanej pracy wskazano również na dodatnie związki między wydajnością pracy i rentownością ziemi (będące pochodnymi produktywności) a rosnącym poziomem zadłużenia, co pokrywa się z wynikami niniejszych analiz. 
$0-0,412$

$0,412-0,476$

$0,476-0,541$

$0,541-1$

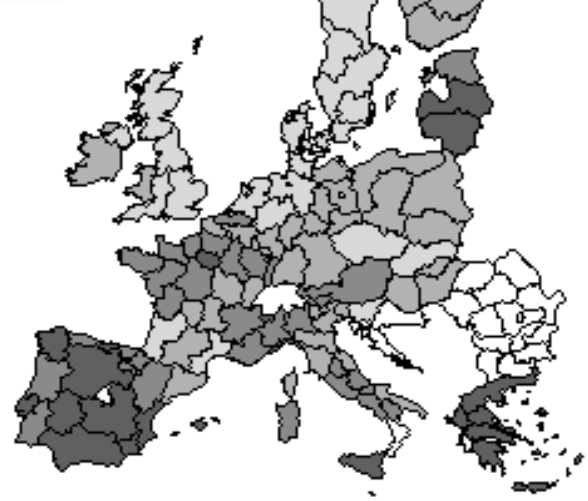

Rysunek 1. Podział regionów Unii Europejskiej

FADN według wartości syntetycznego miernika oceny kondycji finansowej w latach 2005-2007

Źródło: opracowanie własne na podstawie danych FADN.

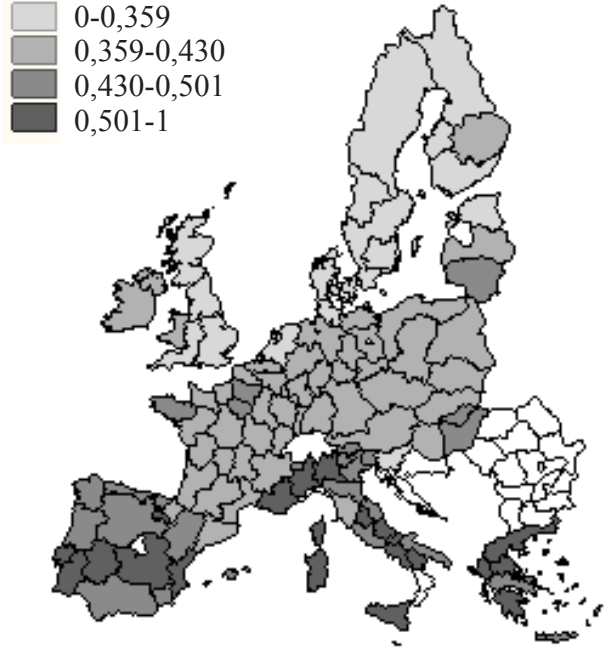

Rysunek 2. Podział regionów Unii Europejskiej FADN według wartości syntetycznego miernika oceny kondycji finansowej w latach 2013-2015

Źródło: opracowanie własne na podstawie danych FADN.

o średnio wysokich wartościach miary syntetycznej znalazły się kolejne regiony hiszpańskie, włoskie (w pierwszym podokresie głównie południowe w drugim północne) oraz część regionów francuskich. W przypadku pierwszego podokresu w drugiej grupie znalazły się również Austria, Flandria czy Hamburg, natomiast w drugim podokresie również m.in. Litwa i dwa regiony węgierskie. Regiony te charakteryzowały się dobrą sytuacją, jeśli chodzi o zadłużenie i płynność, a także wysoką rentownością sprzedaży i kapitału (choć niższą niż w grupie pierwszej). W latach 2005-2007 w grupie regionów o średnio wysokich wartościach miary syntetycznej notowano szczególnie wysoką przeciętną rotację aktywów. Grupa regionów o średnio niskich wartościach miary syntetycznej była najbardziej liczna w obu podokresach i tym samym najbardziej zróżnicowana w układzie przestrzennym. W grupie tej dominowały regiony niemieckie, francuskie, część regionów północnej Europy (głównie fińskie) oraz część regionów z tzw. nowych krajów członkowskich (w tym wszystkie regiony polskie). Poziom zadłużenia oraz zdolność do jego obsługi były na niższym poziomie, jednak szczególną uwagę zwracają niższe przeciętne wartości wskaźników w zakresie rentowności. Rotacja aktywów była bowiem w tych regionach na relatywnie wysokim poziomie, szczególnie w drugim podokresie.

Najmniej liczna była ostatnia grupa (w obu podokresach), która obejmowała regiony o niskiej wartości miary syntetycznej: regiony skandynawskie, brytyjskie, Słowenię (tylko okres 2005-2007) oraz Danię i Holandię. Ostatnie 2 państwa-regiony odznaczały się szczególnie niekorzystną sytuacją finansową w rozumieniu analizy wskaźnikowej. $\mathrm{Z}$ drugiej strony, na tych obszarach rolnictwo jest wysoko rozwinięte. Wskazuje to na paradoks rozwoju rolnictwa, w którym nowoczesne gospodarstwa funkcjonują często w warunkach wysokiego zadłużenia i niskich marż, ale ze względu na dużą skalę produk- 
Tabela 3. Średnie wartości cząstkowych mierników oceny kondycji finansowej gospodarstw reprezentatywnych w regionach FADN UE w poszczególnych grupach regionów

\begin{tabular}{|c|c|c|c|c|c|c|c|c|}
\hline $\begin{array}{l}\text { Wartość miernika } \\
\text { syntetycznego (w nawiasie } \\
\text { liczba regionów w grupie) }\end{array}$ & KOD & $\mathrm{DZO}$ & RMZD & $\mathrm{POO}$ & $\begin{array}{c}\text { ROS } \\
{[\%]}\end{array}$ & $\begin{array}{c}\text { ROE } \\
{[\%]}\end{array}$ & $\mathrm{CZ}$ & RA \\
\hline \multicolumn{9}{|c|}{$2005-2007$} \\
\hline $\mathrm{q}_{\mathrm{i}}>0,54093(22)$ & 480,97 & 0,033 & 39,60 & 756,00 & 54,9 & 13,5 & 22,151 & 0,183 \\
\hline $0,54093>\mathrm{q}_{\mathrm{i}}>0,4765(33)$ & 301,43 & 0,129 & 10,51 & 140,74 & 38,6 & 13,2 & 55,615 & 0,191 \\
\hline $0,4765>\mathrm{q}_{\mathrm{i}}>0,4121$ & 230,21 & 0,138 & 3,67 & 42,96 & 28,2 & 8,4 & 43,222 & 0,163 \\
\hline $\mathrm{q}_{\mathrm{i}}<0,4121(18)$ & 186,34 & 0,147 & 1,90 & 13,23 & 16,0 & 4,3 & 55,760 & 0,120 \\
\hline \multicolumn{9}{|c|}{ 2013-2015 } \\
\hline$q_{i}>0,5012(23)$ & 515,87 & 0,023 & 139,02 & 2059,9 & 47,1 & 11,7 & 21,118 & 0,171 \\
\hline $0,5012>\mathrm{q}_{\mathrm{i}}>0,4299(26)$ & 488,48 & 0,063 & 13,46 & 189,14 & 36,4 & 9,3 & 31,660 & 0,143 \\
\hline $0,4299>\mathrm{q}_{\mathrm{i}}>0,3586(49)$ & 198,92 & 0,179 & 1,78 & 20,55 & 19,5 & 8,2 & 58,336 & 0,164 \\
\hline $\mathrm{q}_{\mathrm{i}}<0,3586(15)$ & 183,03 & 0,211 & 1,39 & 13,07 & 13,2 & 3,8 & 50,365 & 0,096 \\
\hline
\end{tabular}

Źródło: opracowanie własne na podstawie danych FADN.

cji (szczególnie w relacji do czynnika pracy) mają znaczną siłę ekonomiczną i wysokie dochody. Gospodarstwa ostatniej grupy funkcjonowały w warunkach względnie niskiej rentowności, szczególnie kapitałów własnych, niskiej wartości rotacji aktywów oraz względnie wysokiego zadłużenia. Wartości wskaźników dotyczące tej ostatniej kategorii, choć najmniej korzystne na tle pozostałych grup, nie zagrażały jednak stabilności finansowej. Powyższe badania można rozszerzyć również o problem typu produkcyjnego, gdyż w świetle wyników Jacka Kulawika i Renaty Płonki może on istotnie determinować osiągane wyniki finansowe [Kulawik, Płonka 2014].

W drugim etapie badań analizowano wartości współczynników korelacji pomiędzy syntetycznym miernikiem oceny kondycji finansowej gospodarstwa a wskaźnikami produktywności (tab. 4.) - całkowitej (TFP) oraz cząstkowej (kapitału, pracy i ziemi). Można zauważyć, że wszystkie współczynniki korelacji były istotne na poziomie $95 \%$. Samo występowanie korelacji między kondycją finansową oraz produktywnością czynników wytwórczych nie pozwala na ocenę zależności przyczynowo-skutkowych, ale może być wstępem do pogłębionych badań w tym zakresie. Związki między produktywnością i kondycją finansową stają się coraz bardziej wyraźne, gdyż wartości współczynników korelacji w podokresie 2013-2015 były w każdym przypadku wyższe niż w podokresie 2005-2007. Wartości współczynników w pierwszych dwóch kolumnach tabeli 4. wskazują, że korzystniejszej kondycji finansowej gospodarstwa towarzyszyła wyższa produktywność całkowita, jednakże siłę tej zależności należy ocenić jako umiarkowaną. Na złożoność zależności między produktywnością a sytuacją finansową wskazują z kolei wartości współczynników korelacji między wartością miernika syntetycznego i produktywnością poszczególnych czynników. Jeśli chodzi o czynnik kapitału, to zaobserwować można istotny statystycznie i relatywnie silny związek między jego produktywnością a kondycją finansową gospodarstwa. Z kolei w przypadku czynników pracy i ziemi zależność między produktywnością i kondycją finansową jest odwrotnie proporcjonalna, przy czym szczególnie silna w przypadku tego pierwszego czynnika. 
Tabela 4. Tabela korelacji syntetycznego miernika kondycji finansowej i wskaźników produktywności*

\begin{tabular}{|c|c|c|c|c|c|}
\hline \multirow{2}{*}{$\begin{array}{l}\text { Miernik } \\
\text { syntetyczny }\end{array}$} & \multirow[t]{2}{*}{ TFP (1) } & \multirow[t]{2}{*}{ TFP (2) } & \multicolumn{3}{|c|}{ Produktywność } \\
\hline & & & kapitału & pracy & ziemi \\
\hline \multicolumn{6}{|c|}{ Współczynnik korelacji liniowej Pearsona } \\
\hline TOPSIS ‘05-‘07 & 0,317 & 0,316 & 0,620 & $-0,510$ & $-0,422$ \\
\hline TOPSIS ‘ $13-‘ 15$ & 0,377 & 0,380 & 0,756 & $-0,637$ & $-0,596$ \\
\hline \multicolumn{6}{|c|}{ Współczynnik korelacji rang Spearmana } \\
\hline TOPSIS ‘05-‘07 & 0,309 & 0,312 & 0,602 & $-0,468$ & $-0,403$ \\
\hline TOPSIS ‘ $13-‘ 15$ & 0,341 & 0,344 & 0,794 & $-0,622$ & $-0,599$ \\
\hline \multicolumn{6}{|c|}{ Współczynnik korelacji tau Kendalla } \\
\hline TOPSIS ‘05-‘07 & 0,207 & 0,210 & 0,412 & $-0,337$ & $-0,284$ \\
\hline TOPSIS ' $13-‘ 15$ & 0,229 & 0,232 & 0,581 & $-0,459$ & $-0,425$ \\
\hline
\end{tabular}

* wszystkie korelacje istotne na poziomie istotności 0,05 .

Źródło: opracowanie własne na podstawie danych FADN i Eurostat.

Przeprowadzone badania wskazały, że paradoksalnie najlepiej rozwinięte rolniczo regiony (w sensie wynagrodzenia czynnika pracy) charakteryzowały się relatywnie gorszą sytuacją finansową. Wysoce intensywna ścieżka rozwoju (przejście od metod produkcji opartych głównie na pracy i ziemi do metod kapitałochłonnych) w połączeniu z systemem wsparcia publicznego prowadzi do wzrostu produktywności czynników pracy i ziemi i obniżenia produktywności kapitału. Intensyfikacja wymaga jednak nakładów inwestycyjnych, w tym zadłużania gospodarstwa. W regionach południowych rolnictwo ma bardziej tradycyjny charakter, stosuje się znaczne nakłady pracy lub ekstensywny system gospodarowania (środkowa Hiszpania), przez co produktywność tego czynnika jest zwykle niższa. Z drugiej strony, niski poziom nasycenia kapitałem w połączeniu z korzystnymi uwarunkowaniami klimatycznymi pozwala tym gospodarstwom osiągać wysokie stopy zwrotu z zaangażowanego majątku w warunkach niskiego poziomu zadłużenia. Powyższe konstatacje wskazują, że w specyficznym i zróżnicowanym sektorze, jakim jest rolnictwo, wnioskowanie na podstawie tradycyjnej analizy wskaźnikowej nie jest obciążone błędnymi uproszczeniami jedynie wówczas, gdy dokonywane jest na tle innych problemów, jak realizowany model rolnictwa lub produktywność (ewentualnie dochodowość) czynników wytwórczych. Do podobnych wniosków doszli również Walenty Poczta, Joanna Średzińska i Karolina Pawlak, którzy badali związki sytuacji finansowej gospodarstw i ich wyników produkcyjno-ekonomicznych w krajach UE [Poczta i in. 2008].

\section{WNIOSKI}

1. Analiza sytuacji finansowej reprezentatywnych gospodarstw rolnych wskazuje na jej wyraźne zróżnicowane w układzie przestrzennym i jednocześnie względną stabilność w czasie. Porównując dwa badane podokresy, należy wskazać na względną stabilność poziomu zadłużenia gospodarstw oraz pogarszające się średnie wyniki w zakresie rentowności sprzedaży i kapitałów własnych. Nie należy tego jednak oceniać jednoznacznie negatywnie, ponieważ jest to naturalne zjawisko towarzyszące rozwojowi sektora rolnego. Wartości współczynnika zmienności w obu podokresach kształtowały się na podobnym poziomie, co wskazuje, że nie następowała konwergencja gospodarstw w zakresie kondycji finansowej. 
2. Relacje pomiędzy poszczególnymi wskaźnikami oceny kondycji finansowej mogą być związane $\mathrm{z}$ modelem rozwojowym rolnictwa w danym regionie czy dominującymi kierunkami produkcji. Kwestie te wymagają dalszych, pogłębionych badań.

3. Najwyższe wartości syntetycznej miary oceny kondycji finansowej gospodarstw odnotowano przede wszystkim w regionach Europy Południowej (Grecja, Portugalia, część Hiszpanii i Włoch). Gospodarstwa w tych regionach odznaczały się relatywnie niskim poziomem zadłużenia, korzystną sytuacją w zakresie obsługi długu, a także wysoką rentownością i sprawnością działania.

4. Najmniej korzystną sytuację finansową gospodarstw zaobserwowano w Europie Północnej (m.in. Dania, Holandia, część Skandynawii, Niemiec). Gospodarstwa w tych regionach są nowoczesne, wykorzystywana jest intensywna forma gospodarowania, a praca dobrze wynagradzana, jednak wiąże się to z wyższym poziomem zadłużenia i względnie niską rentownością.

5. Zaobserwowano istotne statystycznie związki między kondycją finansową gospodarstw a produktywnością czynników wytwórczych. Korzystna sytuacja finansowa była dodatnio skorelowana z produktywnością kapitału, której wysoki poziom jest charakterystyczny dla regionów południowych z mniej nowoczesnym rolnictwem, ale korzystnymi uwarunkowaniami klimatycznymi. Z kolei gospodarstwa w regionach, w których jest osiągana wysoka produktywność pracy i ziemi, odznaczają się mniej korzystną sytuacją finansową w tradycyjnym jej rozumieniu. Ze względu na dużą skalę produkcji osiągają jednak wysokie dochody.

\section{LITERATURA}

Baer Nawrocka Agnieszka, Natalia Markiewicz, 2010: Zróżnicowanie przestrzenne potencjału produkcyjnego rolnictwa w krajach Unii Europejskiej. „Roczniki Nauk Rolniczych, Seria G”, 97(4), s. 9-15.

Bereżnicka Joanna, 2011: Poziom kapitału obrotowego a możliwości generowania kapitału finansowego w rodzinnych gospodarstwach rolniczych, „Roczniki Nauk Rolniczych, Seria G, Ekonomika Rolnictwa", 98(4), s. 49-55.

Bieniasz Anna, Zbigniew Gołaś, Aleksandra Łuczak, 2013: Zróżnicowanie kondycji finansowej gospodarstw rolnych wyspecjalizowanych w chowie owiec i kóz w krajach Unii Europejskiej, „Roczniki Ekonomii Rolnictwa i Rozwoju Obszarów Wiejskich", 100(1), s. 168-181.

Dańska-Borsiak Barbara, 2011: Dynamiczne modele panelowe w badaniach ekonomicznych. Wydawnictwo Uniwersytetu Łódzkiego.

Deng Hepu Chung-Hsing Yeh, Robert J. Willis, 2000: Inter-company comparison using modified TOPSIS with objective weights. „Computers \& Operations Research”, 27(10), s. 963-973.

Diakoulaki Danae, George Mavrotas, Lefteris Papayannakis, 1995: Determining objective weights in multiple criteria problems: The critic method. „Computers \& Operations Research”, 22(7), s. 763-770.

Escalante Cesar L., Calum G. Turvey, Peter J. Barry, 2009: Farm business decisions and the sustainable growth challenge paradigm, ,Agricultural Finance Review”, 69(2), s. 228-247.

Franc-Dąbrowska Justyna, 2009: Praktyczne zastosowanie wybranych modeli panelowych do oceny sytuacji finansowej przedsiebiorstw rolniczych. ,Zeszyty Naukowe SGGW w Warszawie. Ekonomika i Organizacja Gospodarki Żywnościowej”, 76, s. 31-40.

Goddard Ellen, Weersink Alfons, Chen Kevin, Calum G. Turvey, 1993: Economics of structural change in agriculture, „Canadian Journal of Agricultural Economics/Revue Canadienne d'Agroeconomie", 41(4), s. 475-489.

Gołaś Zbigniew, 2009: Czynniki determinujące rentowność kapitału własnego w rolnictwie, „Journal of Agribusiness and Rural Development", 1(11), s. 75-91.

Gołaś Zbigniew, Kurzawa Izabela 2014: Zastosowanie uporządkowanego modelu logitowego w analizie rentowności branż przemysłu spożywczego, „Zagadnienia Ekonomiki Rolnej”, 1(338), s. 78-96. 
Góral Justyna, Katarzyna Kambo, Jacek Kulawik, Dariusz Osuch, Renata Płonka, Agnieszka PocztaWajda, Adam Wąs, Michał Soliwoda, 2015: Subsidies versus economics, finances and income of farms, Monograph of Multi-annual Programme, Institute Of Agricultural And Food Economics, National Research Institute, Warsaw.

Jepsen Martin Rudbeck i inni, 2015: Transitions in European land-management regimes between 1800 and 2010, „Land Use Policy”, 49, s. 53-64. doi.org/10.1016/j.landusepol, 2015.07.003.

Kulawik Jacek, Renata Płonka, 2014: Subsydia i efektywność ekonomiczno-finansowa a typ produkcyjny gospodarstw osób fizycznych, ,Zagadnienia Ekonomiki Rolnej”, 340(3), s. 3-19.

Majchrzak Anna, Feliks Wysocki, 2007: Potencjat produkcyjny rolnictwa w województwie wielkopolskim. „Roczniki Naukowe Stowarzyszenia Ekonomistów Rolnictwa i Agrobiznesu”, 9(2), s. 217-221.

Moss Charles B., Ashok K. Mishra, Cheikhna Dedah, 2009: Decomposing Agricultural Profitability Using DuPont Expansion and Theil's Information Approach „American Agricultural Economics Association Annual Meetings", Milwaukee, Wisconsin, July 26-28.

Poczta Walenty, Joanna Średzińska, Karolina Pawlak, 2008: Sytuacja finansowa gospodarstw rolnych krajów UE sklasyfikowanych wedlug ich wyników produkcyjno-ekonomicznych, „Zeszyty Naukowe Szkoły Głównej Gospodarstwa Wiejskiego w Warszawie. Problemy Rolnictwa Światowego", 4(19), s. 379-387.

Restuccia Diego, Tao Yang Dennis, Zhu Xiaodong 2008: Agriculture and aggregate productivity. A quantitative cross-country analysis, „Journal of Monetary Economics”, 55(2), s. 234-250.

Soliwoda Michał, 2014: Finanse rolnictwa wobec współczesnych wyzwań gospodarczych i spolecznych-perspektywy rozwoju. „Zagadnienia Ekonomiki Rolnej”, 341(4), s. 68-86.

Soliwoda Michał, 2015: Dylematy wokót wymiaru finansowego zrównoważenia gospodarstw rolniczych, „Zagadnienia Ekonomiki Rolnej”, 344(3), s. 112-128.

Wasilewski Mirosław, Tomasz Felczak, 2011: Strategia płynności finansowej przedsiębiorstw rolniczych w zależności od rentowności aktywów, „Zeszyty Naukowe SGGW w Warszawie Ekonomika i Organizacja Gospodarki Żywnościowej”, 39, s. 49-59.

Wasilewski Mirosław, Magdalena Mądra, 2008: Efektywność gospodarstw indywidualnych w zależności od zadtużenia i sity ekonomicznej, „Zeszyty Naukowe SGGW w Warszawie. Ekonomika i Organizacja Gospodarki Żywnościowej”, 64, s. 87-99.

Wysocki Feliks 2010: Metody taksonomiczne w rozpoznawaniu typów ekonomicznych rolnictwa i obszarów wiejskich, Wydawnictwo Uniwersytetu Przyrodniczego w Poznaniu, Poznań.

\section{Bazyli Czyżewski, Łukasz Kryszak \\ FINANCIAL CONDITION OF AGRICULTURAL HOLDINGS IN EU FADN REGIONS AND ITS RELATION TO FACTOR PRODUCTIVITY}

\section{Summary}

The aim of the study was to assess the financial condition of representative agricultural holdings in the EU FADN regions and to identify the relation between the financial condition of farms and productivity of production factors, as well as total productivity (TFP). A synthetic metric (based on TOPSIS method) for the assessment of the financial situation of the holding was used, along with correlation indicators in the second step of study. The representative farms in the EU FADN regions are characterised by a highly diversified financial situation, with the highest values of the synthetic meter in Southern Europe (Greece, Portugal, parts of Spain and Italy). The farms in these regions were characterised by a relatively low level of debt, favourable situation in terms of debt service, as well as high profitability and efficiency of operations. Statistically significant relations between financial condition of farms and productivity of production factors were observed. Positive in the case of the capital factor and TFP, and negative in relation to work and land.

Adres do korespondencji:

Dr hab. Bazyli Czyżewski, prof. UEP, mgr Łukasz Kryszak Uniwersytet Ekonomiczny w Poznaniu, Katedra Makroekonomii i Gospodarki Żywnościowej al. Niepodległości 10, 61-875 Poznań e-mail: bazyli.czyzewski@ue.poznan.pl, lukasz.kryszak@ue.poznan.pl 